\title{
Soda-Anthraquinone Pulping Optimization of Oil Palm Empty Fruit Bunch
}

\begin{abstract}
Nurul Husna Mohd Hassan, ${ }^{\mathrm{a}, *}$ Noorshashillawati Azura Mohammad, ${ }^{\mathrm{a}}$ Mazlan Ibrahim, ${ }^{\mathrm{b}}$ Nor Yuziah Mohd Yunus, ${ }^{a}$ and Siti Noorbaini Sarmin ${ }^{\text {a }}$

The influence of soda-anthraquinone (AQ) pulping conditions on paper properties of oil palm empty fruit bunches was studied using Response Surface Methodology (RSM) based on Central Composite Design (CCD). The alkali charge, $\mathrm{NaOH}(A)$, pulping temperature $(T)$, and pulping time $(t)$ ranged between 20 and $30 \%, 160$ and $180{ }^{\circ} \mathrm{C}$, and 60 and 120 minutes, respectively. The mechanical properties evaluated for the handsheets produced were the tensile index, tearing index, bursting index, folding endurance, zero-span tensile strength, and the optical properties (brightness and opacity). The effects of soda-AQ pulping conditions on oil palm empty fruit bunch paper were elucidated by the regression models obtained. The optimum pulping condition were at $27.3 \%$ alkali charge, 160 ${ }^{\circ} \mathrm{C}$, and $60 \mathrm{~min}$ that produced paper properties with $26.8 \mathrm{~N} . \mathrm{m} / \mathrm{g}$ tensile index, $7.95 \mathrm{mN} . \mathrm{m}^{2} / \mathrm{g}$ tearing index, $5.32 \mathrm{kPa} \cdot \mathrm{m}^{2} / \mathrm{g}$ bursting index, 1.70 $\log _{10}$ folding endurance, $46.2 \mathrm{~N}$ zero-span tensile strength, $51.8 \%$ brightness, and $95.8 \%$ opacity.
\end{abstract}

Keywords: Empty fruit bunch (EFB); Soda-AQ pulping; Mechanical paper properties; Optical paper properties; Response surface methodology (RSM)

Contact information: a: Study Centre of Wood Industry, Faculty of Applied Sciences, Universiti Teknologi MARA Pahang, 26400 Jengka, Pahang, Malaysia; b: School of Industrial Technology, Universiti Sains Malaysia, 11800 Minden, Pulau Pinang, Malaysia; *Corresponding author: nurulhusna@uitm.edu.my

\section{INTRODUCTION}

Oil palm (Elaeis guineensis) originated from West Africa, and it is a crucial and useful plant grown in plantations in South America and Asia (Pye 2019). It was first introduced to Malaysia in Tenamaran Estate, Selangor, in 1871. Malaysia is the second largest producer of oil palm (41\% of world production) after Indonesia (44\%) (Onoja et al. 2018). In Malaysia, the oil palm industry is the fourth largest contributor to the Malaysian gross national income (GNI). Initially, oil palm tree was planted due to its aesthetics and decorative nature. However, it has great potential that can be harnessed to serve the rural and urban community.

Oil palm is very productive, able to capture large amounts of carbon, and provides good protection to the soil (Mutsaers 2019). However, palm oil plantations produce vast amounts of biomass such as empty fruit bunches (EFB), oil palm trunk (OPT), oil palm frond (OPF), palm kennel shells (PKS), mesocarp fibers (MF), and palm oil mill effluent (POME) (Tan and Lim 2019). Open burning, landfill dumping, and large quantities of oil palm biomass waste contribute to environmental pollution and negative health impacts. Considering environmental awareness, the abundant oil palm biomass must be handled properly and with care. 
Biomass can be used as feedstock, biochar, pellets biogas, and non-energy products (Loh 2017). Oil palm fiber contains large amount of cellulose (21.4\%), hemicellulose (21.7\%), lignin (34.3\%), and extractives (9.9\%) (Rahman and Amin 2019; Mahmud and Zakaria 2020; Pereira et al. 2020; Poh et al. 2020).

As one of the major countries in palm oil production, some of the waste from the oil palm plantation such as oil palm fronds and empty fruit bunches are a great potential source of non-wood industry; for example, they can be used as raw material in the paper industry (Li et al. 2019; Mannai et al. 2019; Soloi and Hou 2019). Many studies have been conducted to find a sulfur-free additive for alkaline pulping liquors (Agustin et al. 2019; Fernández-Rodríguez et al. 2019; Hyväkkö et al. 2019; Elzaki et al. 2020; Gomes et al. 2020). Hydrazine, hydroxylamine, and sodium borohydride are sulfur-free additives, but these additives are more expensive than anthraquinone (AQ). AQ has a lower cost and has been widely used in mill applications (Hart and Rudie 2014).

AQ has good effects on kraft and soda pulping, even when added in very small quantities. AQ functions very effectively in this application. Furthermore, AQ can be added to kraft pulping liquors to improve the yield and pulp properties (Casey 1983). AQ behaves as a redox catalyst during alkaline pulping, leading to a lower lignin content in the pulp, an increase in screened pulp yield, and a decrease in rejects (Shakhes et al. 2011). AQ is used as a digester additive in the production of pulp by alkaline processes, including the kraft, the alkaline sulfite, and the soda-AQ processes. The AQ is a redox catalyst. The reaction mechanism may involve a single electron transfer. AQ functions by oxidizing the reducing end of polysaccharides in the pulp, i.e., cellulose and hemicellulose, and thereby protecting it from alkaline degradation (peeling) (Samp 2008; Tutus et al. 2016).

Jimenez et al. (2009) reported the influence of soda-AQ pulping variables (temperature, time, and soda concentration) of palm oil empty fruit bunches (EFB) paper sheets. The soda concentrations, temperatures, and times used were 10\%, 15\%, and $20 \%$ (on dried raw material); 155,170 , and $185^{\circ} \mathrm{C}$; and 30, 60, and $90 \mathrm{~min}$, respectively. They found that the optimum operating conditions $\left(15 \%\right.$ soda, $170{ }^{\circ} \mathrm{C}, 70 \mathrm{~min}$, and 2400 number of PFI beating revolutions) produced paper properties departing by less than $12 \%$ from their optimum values $(59.63 \mathrm{Nm} / \mathrm{g}$ tensile index, $4.48 \%$ stretch, $4.17 \mathrm{kN} / \mathrm{g}$ burst index and $7.20 \mathrm{~m} . \mathrm{Nm}^{2} / \mathrm{g}$ tear index), and a beating grade of 47.5 degrees $\mathrm{SR}$, acceptable to obtain paper sheets.

Masrol et al. (2017) pulped naturally dried durian rind under soda-AQ pulping process with $18 \%$ to $22 \%$ alkali charge, $0 \%$ to $0.1 \%$ AQ charge, $90 \mathrm{~min}$ to $150 \mathrm{~min}$ of cooking time and $150{ }^{\circ} \mathrm{C}$ to $170{ }^{\circ} \mathrm{C}$ to investigate the effect of pulping variables on the characteristics of the pulp and paper. They also conducted pulping condition with $0 \%$ of AQ charge for comparison. Results indicated that the best screen yield percentage, reject yield percentage, freeness, drainage time, tear index, number of folds, and optical properties were shown by the pulp produced with combination of the highest active alkali (22\%), AQ charge $(0.1 \%)$, cooking time $(150 \mathrm{~min})$, and cooking temperature $\left(170{ }^{\circ} \mathrm{C}\right)$ except for apparent density, tensile index, and burst index.

Hart and Rudie (2014) reported very comprehensive details about the AQ usage since the year 1967, and they also reported on the study conducted by the U.S. Food and Drug Administration (FDA) on AQ in pulping that only completed in the year 1987. The report also emphasized that the usage of AQ in pulping should be stopped for the production of paper and paperboard with direct contact with food products. It also mentioned that, in the event of AQ addition, FDA approved the usage of less than $0.1 \%$ on oven-dry wood in the lignocellulosic material pulping. Thus only the utilisation of $0.1 \%$, 
for this study on the oil palm EFB was done. The application of paper is suggested for writing and printing paper or other non-food contact products. Omer et al. (2019) reported that the pulps produced from okra soda-AQ are suitable for production of printing and writing papers. Azizi Mossello et al. (2010) also studied kenaf soda-AQ for paper and paperboard production.

The aim of the study was to determine the optimum pulping condition for EFB fiber, which can be used as an alternative materials for paper industry, by using more environmental friendly process which is soda-AQ pulping compared to the commercial kraft pulping. The pulping conditions variables were set based on the target paper properties to be achieved.

\section{EXPERIMENTAL}

\section{EFB Washing}

Empty fruit bunches (EFB) obtained from SABUTEK Sdn. Bhd., Teluk Intan, Perak in the form of fibers were used as raw material. The fibers were soaked overnight and washed with water to remove the debris such as soil and dust. The fibers were then sun-dried, and the moisture content was determined prior to the pulping process.

\section{Soda-Anthraquinone Pulping}

Response Surface Methodology (RSM) was used to identify the optimum cooking conditions for the studied variables. The cooking parameters included temperature, time, and alkali $(\mathrm{NaOH})$ at ranges of 160 to $180{ }^{\circ} \mathrm{C}, 60$ to $120 \mathrm{~min}$, and 20 to $30 \%$, respectively. There are fixed factors such as the time of $90 \mathrm{~min}$ to reach the pulping temperature. The AQ percentage was set at $0.1 \%$ based on the oven-dried EFB, and $300 \mathrm{~g}$ oven dried EFB was used for each pulping process.

The soda-anthraquinone pulping process is shown in Table 1. According to this program design, 20 experiments were conducted based on the selected range of pulping parameters. The pulping choice followed the experimental sequencing. This sequencing allows a completely randomized pulping process.

\section{Paper Making}

Papermaking method was based on TAPPI T205 om-88 (1994), with slight modification, with a target grammage of $60 \mathrm{~g} / \mathrm{m}^{2}$. The laboratory handsheets were cut to specified measurements for testing in accordance with TAPPI T220 om-88 (1994).

\section{Properties Testing}

Tensile strength

Tensile testing was done using Tensile Strength Tester Model LLYOD Instrument 9911 (Lenniko Resources, Bumi Sains, Malaysia) based on TAPPI T404 cm-92 (1994).

\section{Tear resistance}

The test was carried out with an Elmendorf Tearing Tester Model Protear RS232 (Thwing-Albert Instrument Company, Philadelphia, PA, USA) based on TAPPI T414 om88 (1994). 
Table 1. Sequencing of Soda-Anthraquinone Pulping

\begin{tabular}{|c|c|c|c|c|}
\hline \multirow{2}{*}{ No. } & Experiment & \multicolumn{3}{|c|}{ Pulping Parameters } \\
\cline { 3 - 5 } & Sequence & $\mathrm{T}\left({ }^{\circ} \mathrm{C}\right)$ & $\mathrm{t}(\mathrm{min})$ & $\mathrm{A}(\%)$ \\
\hline 1 & 4 & 160 & 60 & 20 \\
\hline 2 & 19 & 180 & 60 & 20 \\
\hline 3 & 6 & 160 & 120 & 20 \\
\hline 4 & 8 & 180 & 120 & 20 \\
\hline 5 & 2 & 160 & 60 & 30 \\
\hline 6 & 7 & 180 & 60 & 30 \\
\hline 7 & 1 & 160 & 120 & 30 \\
\hline 8 & 18 & 180 & 120 & 30 \\
\hline 9 & 9 & 153 & 90 & 25 \\
\hline 10 & 5 & 187 & 90 & 25 \\
\hline 11 & 20 & 170 & 40 & 25 \\
\hline 12 & 15 & 170 & 141 & 25 \\
\hline 13 & 17 & 170 & 90 & 16.6 \\
\hline 14 & 3 & 170 & 90 & 33.4 \\
\hline 15 & 12 & 170 & 90 & 25 \\
\hline 16 & 13 & 170 & 90 & 25 \\
\hline 17 & 14 & 170 & 90 & 25 \\
\hline 18 & 16 & 170 & 90 & 25 \\
\hline 19 & 11 & 170 & 90 & 25 \\
\hline 20 & 10 & 170 & 90 & 25 \\
\hline
\end{tabular}

\section{Folding endurance}

A Folding Endurance Tester Model KRK (Kumagai Riki Kogyo Co. Ltd., Nerima, Tokyo, Japan) was used based on TAPPI T423 om-88 (1994).

\section{Burst strength}

Burst strength was conducted based on TAPPI T403 om-91 (1994) using Bursting Strength Tester Model 3720 (Mullen Testers, Massachusetts, USA).

\section{Zero-span tensile strength}

The test is designed for observation of the actual fiber strength in the paper. Equipment used is Zero-span Tensile Strength Model TESTOMETRIC M250-2-UK (Testometric Co. Ltd., Lancashire, England) based on TAPPI T231 cm-85 (1994) method.

\section{Appearance-related tests}

The brightness test was conducted in accordance with TAPPI T452 om-92 (1994) using Brightness and Opacity Tester Model S-5 BOC (Technidyne Corporation, New Albany, IN, USA). The opacity test was done using the same machine used for brightness and based to TAPPI T425 om-91 (1994).

\section{Optimization of Pulping Parameters}

To get the desired paper quality, the paper criteria was set to a fixed value. A few pulping level factors were suggested by the Design-Expert Version 7.0 Software, by StatEase, Inc., as stated in Table 2. An experiment was done using the solution factors at level one (1) to obtain nearest values according to predicted values for pulp and paper properties. 


\section{RESULTS AND DISCUSSION}

\section{Pulping Yield}

Soda-AQ oil palm EFB fiber pulping with pulping parameters of alkali charge, $\mathrm{NaOH}(\mathrm{A})$, pulping temperature ( $T$ ), and pulping time $(t)$ ranging between 20 and $30 \%$, 160 and $180{ }^{\circ} \mathrm{C}$, and 60 and $120 \mathrm{~min}$, were conducted and the total yield for the pulping condition ranges from $35.70 \%$ to $58.87 \%$. These gave an initial indication on how the total yield is dependent on the pulping conditions.

The total yield was the lowest as two pulping factors namely temperature and alkali percent dosage were at the maximum value. High temperature and high alkali content caused more pulp degradation, which led to lower yield. The screened yield ranged between $30.37 \%$ and $56.07 \%$. It is believed that the pulping factors were at optimum level, namely low temperature with short time and high alkali dosage (Nurul Husna et al. 2018).

\section{Tensile Index}

According to Browning (1977), the unique properties of a paper sheet is determined by the factors that mutually related with natural fibers, on how the fibers bonded during paper making, pulping methods used, and the paper drying processes. Table 3 shows the tensile index for paper tested. Tensile index ranged between 18.43 and $30.95 \mathrm{Nm} / \mathrm{g}$. Testing results were reported on the basis of the testing index to compromise the grammage differences for each sheet of paper.

\section{Tensile Index ANOVA analysis}

Table 4 shows that at Sequential Model Sum of Squares (SMSS), the linear models is preferred because it gave a lower significant Prob. F at 0.0080 compared to 0.2288 for the quadratic model. The insignificant value at Lack of Fit (LOF) Test quadratic model was higher than the linear model value. However, the linear model was more appropriate because it had a higher $\mathrm{R}^{2}$ value and lower Predicted Residual Error Sum of Squares (PRESS) value than the quadratic model. Equation 1 represents responds surface equation for the tensile index linear model,

$$
\text { Tensile index }(\mathrm{Nm} / \mathrm{g})=+68.73-0.16 \boldsymbol{T}-0.052 \boldsymbol{t}-0.47 \boldsymbol{A}
$$

where $\boldsymbol{T}$ is the temperature, $\boldsymbol{t}$ is the time and $\boldsymbol{A}$ is the alkalinity.

\section{Effect of the pulping factors on the tensile index}

Based on the perturbation plot for the tensile index in Fig. 1, temperature and alkaline were selected to represent the $\mathrm{X}$ - and $\mathrm{Y}$-axis, respectively, because they gave more influence than the time factor. However, the timing also played a role in the index because the tensile index decreased when the time was extended from $60 \mathrm{~min}$ to $90 \mathrm{~min}$ and 120 $\min$.

Overall, the index decreased when the temperature and the alkaline increased. The strength properties of paper depend on the strength of the individual fiber and bonding strength between fibers. The bonding strength between fibers formed from the hydrogen bonding arises from the physical connection between hydroxyl groups at the surface of the fiber (Maloney et al. 1997; Schmied et al. 2013; Przybysz et al. 2016). 
Table 2. Pulping Factors Level Suggested by Design Expert Software for Optimum Paper Properties

\begin{tabular}{|c|c|c|c|c|c|c|c|c|c|c|c|}
\hline \multirow[t]{2}{*}{ Solution } & \multicolumn{3}{|c|}{ Pulping Factors } & \multicolumn{7}{|c|}{ Paper Properties } & \multirow[t]{2}{*}{ Achievability } \\
\hline & $\begin{array}{c}T \\
\left({ }^{\circ} \mathrm{C}\right)\end{array}$ & $\begin{array}{c}t \\
(\mathrm{~min})\end{array}$ & $\begin{array}{c}A \\
(\%)\end{array}$ & $\begin{array}{c}\text { Tensile } \\
\text { Index }\end{array}$ & $\begin{array}{l}\text { Burst } \\
\text { Index }\end{array}$ & $\begin{array}{l}\text { Tear } \\
\text { Index }\end{array}$ & $\begin{array}{c}\text { Folding } \\
\text { Endurance }\end{array}$ & $\begin{array}{l}\text { Zero span } \\
\text { Index }\end{array}$ & Brightness & Opacity & \\
\hline 1 & 160.00 & 60.00 & 27.30 & 26.77 & 5.32 & 7.95 & 1.70 & 46.24 & 51.79 & 95.84 & 0.713 \\
\hline 2 & 160.21 & 60.10 & 27.28 & 26.74 & 5.31 & 7.93 & 1.69 & 46.23 & 51.81 & 95.85 & 0.711 \\
\hline
\end{tabular}

Table 3. Tensile Index, Tearing Index, Folding Endurance, Bursting Index, Zero Span Strength, Brightness, and Opacity of Oil Palm EFB Paper*

\begin{tabular}{|c|c|c|c|c|c|c|c|c|c|c|c|c|c|}
\hline \multirow{3}{*}{ No. } & \multicolumn{6}{|c|}{ Pulping Factors Combination Rate } & \multirow{3}{*}{$\begin{array}{c}\text { Tensile } \\
\text { Index } \\
\text { (N.m/g) }\end{array}$} & \multirow{3}{*}{$\begin{array}{l}\text { Tearing } \\
\text { Index } \\
\left(\mathrm{mN} \cdot \mathrm{m}^{2} / \mathrm{g}\right)\end{array}$} & \multirow{3}{*}{$\begin{array}{c}\text { Folding } \\
\text { Endurance } \\
\left(\log _{10}\right)\end{array}$} & \multirow{3}{*}{$\begin{array}{l}\text { Bursting } \\
\text { Index } \\
\left(\mathrm{kPa} \cdot \mathrm{m}^{2} / \mathrm{g}\right.\end{array}$} & \multirow{3}{*}{$\begin{array}{l}\text { Zero- } \\
\text { span } \\
(\mathrm{N})\end{array}$} & \multirow{3}{*}{$\begin{array}{c}\text { Brightness } \\
(\%)\end{array}$} & \multirow{3}{*}{$\begin{array}{c}\text { Opacity } \\
(\%)\end{array}$} \\
\hline & \multicolumn{3}{|c|}{ Code } & \multicolumn{3}{|c|}{ Actual Value } & & & & & & & \\
\hline & $T$ & $t$ & $A$ & $T\left({ }^{\circ} \mathrm{C}\right)$ & $t(\min )$ & $A(\%)$ & & & & & & & \\
\hline 1 & -1 & -1 & -1 & 160 & 60 & 20 & 30.95 & 9.21 & 2.23 & 5.50 & 38.85 & 46.88 & 95.79 \\
\hline 2 & +1 & -1 & -1 & 180 & 60 & 20 & 28.19 & 8.13 & 2.12 & 5.56 & 55.28 & 49.78 & 96.26 \\
\hline 3 & -1 & +1 & -1 & 160 & 120 & 20 & 27.91 & 8.96 & 2.06 & 5.73 & 46.77 & 48.68 & 95.92 \\
\hline 4 & +1 & +1 & -1 & 180 & 120 & 20 & 26.28 & 7.90 & 1.74 & 5.19 & 45.96 & 52.56 & 96.50 \\
\hline 5 & -1 & -1 & +1 & 160 & 60 & 30 & 28.28 & 7.98 & 1.59 & 5.42 & 44.67 & 54.56 & 95.66 \\
\hline 6 & +1 & -1 & +1 & 180 & 60 & 30 & 25.24 & 7.45 & 1.54 & 4.96 & 45.58 & 54.34 & 96.96 \\
\hline 7 & -1 & +1 & +1 & 160 & 120 & 30 & 22.90 & 7.96 & 1.28 & 5.15 & 43.54 & 54.84 & 94.92 \\
\hline 8 & +1 & +1 & +1 & 180 & 120 & 30 & 24.16 & 6.49 & 1.44 & 5.14 & 39.56 & 55.84 & 97.99 \\
\hline 9 & 1.682 & 0 & 0 & 153 & 90 & 25 & 27.46 & 7.95 & 1.78 & 5.29 & 46.96 & 47.12 & 96.66 \\
\hline 10 & $\begin{array}{c}+1.68 \\
2\end{array}$ & 0 & 0 & 187 & 90 & 25 & 18.16 & 6.21 & 1.14 & 4.72 & 37.01 & 52.54 & 97.24 \\
\hline 11 & 0 & -1.682 & 0 & 170 & 40 & 25 & 30.83 & 8.07 & 2.13 & 5.80 & 57.00 & 52.06 & 95.45 \\
\hline 12 & 0 & +1.682 & 0 & 170 & 141 & 25 & 24.93 & 6.88 & 1.40 & 5.11 & 39.61 & 52.12 & 97.30 \\
\hline 13 & 0 & 0 & -1.682 & 170 & 90 & 16.6 & 29.48 & 9.10 & 2.36 & 5.61 & 51.95 & 39.58 & 98.26 \\
\hline 14 & 0 & 0 & +1.682 & 170 & 90 & 33.4 & 18.43 & 6.50 & 1.06 & 5.03 & 36.18 & 56.40 & 96.58 \\
\hline 15 & 0 & 0 & 0 & 170 & 90 & 25 & 19.77 & 6.35 & 1.23 & 4.66 & 42.97 & 53.44 & 96.63 \\
\hline 16 & 0 & 0 & 0 & 170 & 90 & 25 & 21.13 & 6.66 & 1.11 & 4.72 & 39.23 & 52.48 & 97.39 \\
\hline 17 & 0 & 0 & 0 & 170 & 90 & 25 & 25.25 & 7.62 & 1.67 & 5.03 & 40.25 & 53.12 & 97.02 \\
\hline 18 & 0 & 0 & 0 & 170 & 90 & 25 & 24.64 & 7.17 & 1.45 & 5.11 & 51.00 & 53.32 & 97.13 \\
\hline 19 & 0 & 0 & 0 & 170 & 90 & 25 & 24.46 & 7.69 & 1.74 & 5.14 & 46.71 & 52.74 & 96.48 \\
\hline 20 & 0 & 0 & 0 & 170 & 90 & 25 & 14.95 & 5.09 & 0.67 & 4.71 & 41.11 & 53.76 & 96.74 \\
\hline
\end{tabular}

${ }^{*}$ Each data provided was average of 10 readings with SD at 0.08 to 0.36 for tensile, tearing, folding, bursting and zero-span index, while average of 5 readings with SD at 0.23 to 1.06 for brightness and opacity 
Table 4. Tensile Index ANOVA Analysis

\begin{tabular}{|c|c|c|c|c|}
\hline $\begin{array}{c}\text { Paper } \\
\text { mechanical } \\
\text { properties }\end{array}$ & Model & $\begin{array}{c}\text { Sequential Model } \\
\text { Sum of Squares } \\
\text { (SMSS)* }^{*}\end{array}$ & $\begin{array}{l}\text { Lack of Fit Test } \\
(\text { LOF })^{\#}\end{array}$ & $\begin{array}{l}\text { Model Summary } \\
\text { Statistic (MSS) } \ddagger\end{array}$ \\
\hline \multirow{2}{*}{$\begin{array}{l}\text { Tensile Index, } \\
\text { Nm/g }\end{array}$} & Linear & $\begin{array}{c}\text { F-value }=5.75 \\
\text { Prob. } F=0.0080\end{array}$ & $\begin{array}{c}F \text {-value }=1.53 \\
\text { Prob. } F=0.3624\end{array}$ & $\begin{array}{c}R^{2}=0.2677 \\
\text { PRESS }=195.59\end{array}$ \\
\hline & Quadratic & $\begin{array}{c}\text { F-value }=1.69 \\
\text { Prob. } F=0.2288\end{array}$ & $\begin{array}{c}\text { F-value }=1.16 \\
\text { Prob. } F=0.4553\end{array}$ & $\begin{array}{c}R^{2}=-0.1272 \\
\text { PRESS }=301.06\end{array}$ \\
\hline
\end{tabular}

When the lignin was removed from the fibers, the fibers become closer to each other and generated a wide contact area between fibers and thus increased the relative bonding area between fibers. As more bonding area is formed, the paper acquires stronger properties. However, the decrease in the tensile index in this study refers to fibers that have experienced severe degradation due to the use of high temperature and alkali, which is associated with long pulping time. Extreme degradation caused the fibers to become weak and break easily upon the imposition of an external force (Ikramullah et al. 2018).

Therefore, temperature and alkaline charge should be used at medium levels so that the fibers are not exposed to improper severity. According to Casey (1980), degradation of carbohydrates causes the fibers to become weak, which lowers the tensile index. Carbohydrate degradation can occur with the use of high alkaline, temperature, and time.

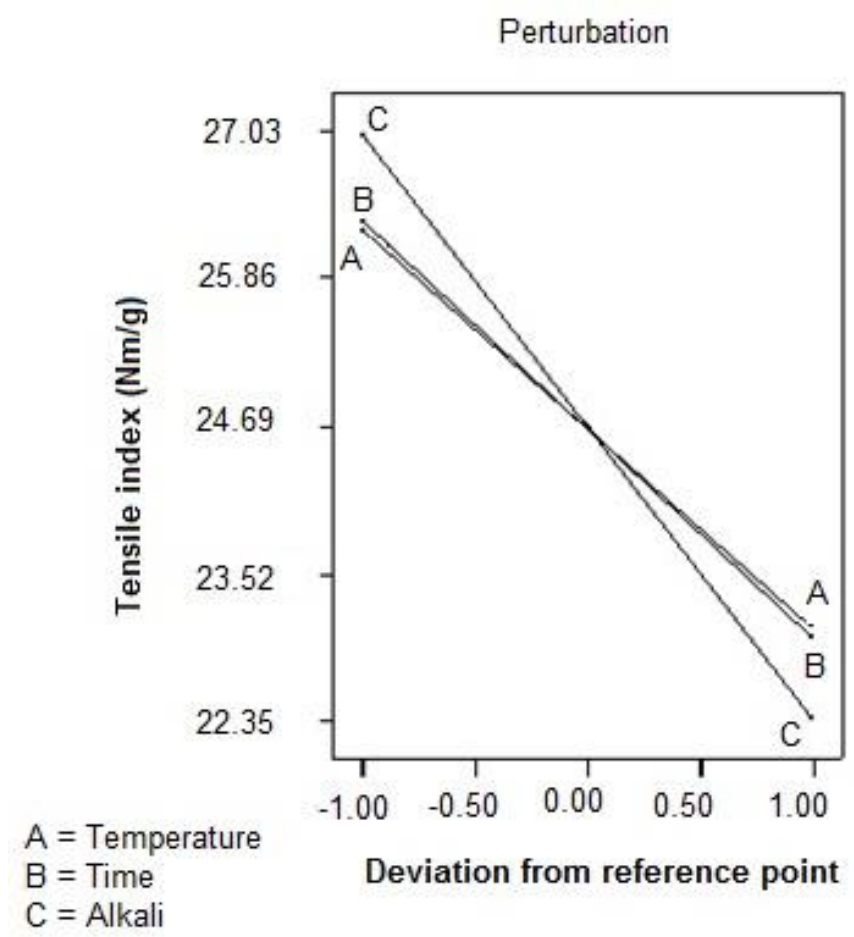

Fig. 1. Tensile index perturbation plot 


\section{Tearing Resistance}

Tearing resistance refers to the internal structure of a paper, but its value is sometimes also influenced by the surface treatment applied. Table 3 shows the range for the tearing index is between 5.09 to $9.22 \mathrm{mN} . \mathrm{m}^{2} / \mathrm{g}$. Generally, the pulping factors affecting tearing index response followed the differences of more than $4 \mathrm{mN} \cdot \mathrm{m}^{2} / \mathrm{g}$.

\section{Tearing Index ANOVA analysis}

Table 5 shows that the linear model from SMSS better fits the results with lower value of Prob. F. Although the insignificant quadratic model (0.9169) has a higher value than the linear model (0.7706), a fixed linear model was selected because it has a high $\mathrm{R}^{2}$ and lower PRESS. Equation 2 describes the response equation for the tearing index linear model.

$$
\text { Tearing index }\left(\mathrm{mN} \cdot \mathrm{m}^{2} / \mathrm{g}\right)=+20.21-0.052 \mathbf{T}-8.503 \times 10^{-3} \mathbf{t}-0.13 \mathbf{A}
$$

Table 5. Tearing Index ANOVA Analysis

\begin{tabular}{|c|c|c|c|c|}
\hline $\begin{array}{c}\text { Paper } \\
\text { mechanical } \\
\text { properties }\end{array}$ & Model & $\begin{array}{c}\text { Sequential Model } \\
\text { Sum of Squares } \\
(\text { SMSS) }\end{array}$ & $\begin{array}{c}\text { Lack of Fit Test } \\
(\text { LOF) }\end{array}$ & $\begin{array}{c}\text { Model Summary } \\
\text { Statistic (MSS) } \ddagger\end{array}$ \\
\hline \multirow{2}{*}{$\begin{array}{c}\text { Tearing index, } \\
\text { mN.m } / g\end{array}$} & Linear & $\begin{array}{c}\text { F-value }=4.81 \\
\text { Prob. } F=0.0142\end{array}$ & $\begin{array}{c}\text { F-value }=0.61 \\
\text { Prob. } F=0.7706\end{array}$ & $\begin{array}{c}\mathrm{R}^{2}=0.2968 \\
\text { PRESS }=14.92\end{array}$ \\
\cline { 2 - 5 } & Quadratic & $\begin{array}{c}\text { F-value }=1.43 \\
\text { Prob. } F=0.2941\end{array}$ & $\begin{array}{c}\text { F-value }=0.26 \\
\text { Prob. } F=0.9169\end{array}$ & $\begin{array}{c}\mathrm{R}^{2}=0.2259 \\
\text { PRESS }=16.42\end{array}$ \\
\hline
\end{tabular}

${ }^{*}$ Choose model with significant Prob. F (Prob. F $<0.05$ )

\# Choose model with insignificant Prob. F (Prob. F >0.10)

$\ddagger$ Choose model with high $\mathrm{R}^{2}$ and low PRESS

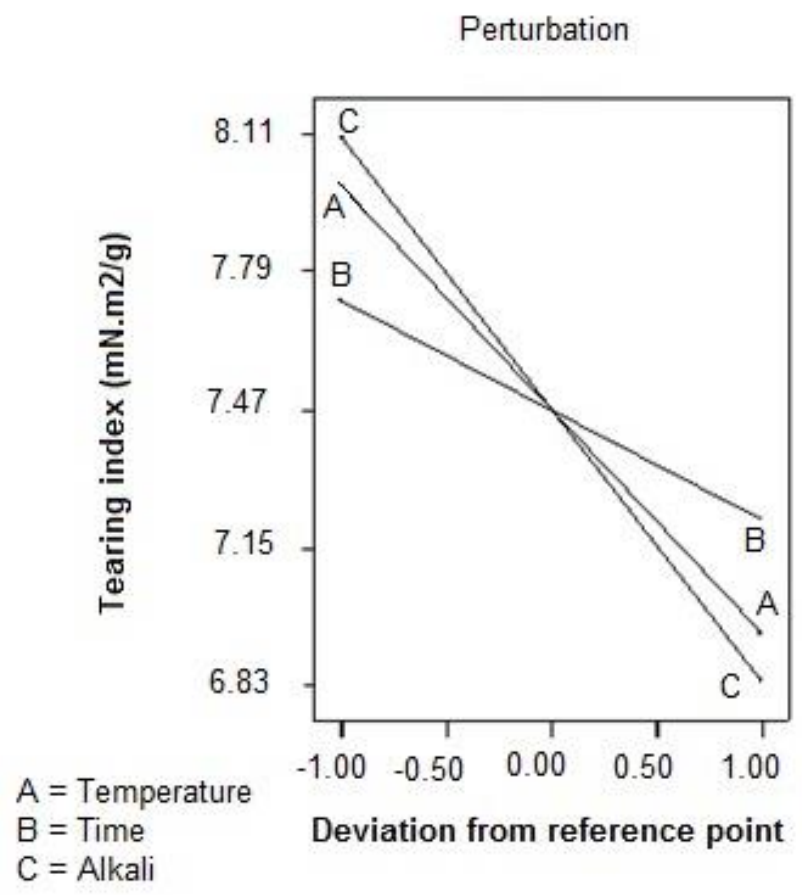

Fig. 2. Tearing index perturbation plot 


\section{Effects of the pulping factors on the tearing index}

The perturbation plot for tearing index (Fig. 2) shows that the temperature and alkaline factors had stronger influences on the tearing index. The time factor had a lesser effect on the tearing index. The tearing properties were more influenced by the dose of alkali and temperature used. At a higher percentage of alkali and temperature, the tearing index value was lower.

The tearing phenomenon involves the pulling-out of the fibers from the paper and breakage of the fibers. Tearing index depends on the length of fibers in a paper. The average length of fibers in a raw material may not be changed during the process of pulping, but the degree of hydrogen bonding may depend on the properties of the fibers and chemical treatment to severity level of the fibers (Zhao et al. 2002).

According to ASTM D689 (1963), the tearing index also depends on the density of the paper. Tearing index increased proportionally with the increasing of the paper density (Nurul Husna et al. 2014). This is due to the fibers arrangement to each other, thus producing high density. Fiber was also difficult to pull out because the bonding between aligned fibers were stronger than bonding in bulky paper.

Long fibers gave higher tearing resistance than short fibers (ASTM D689 1963). This is because long fiber yields more surface contact area per fiber, thus producing a greater cumulative amount of bonding. In this study, the tearing index decreased with increasing alkali charge and temperature. The fiber exposed to degradation and fiber strength decreased. When the individual fiber is weak, it was unable to form a strong hydrogen bonding between the fibers during the formation of the paper. Extreme pulping factors also caused the pulp to become weak and unable to withstand the breakage upon the imposition of external force. This resulted in paper that is easily tear off and has a low tearing index.

\section{Folding Endurance}

Folding endurance is an empirical test that measures the number of folds that can be recovered by any paper before the tensile strength falls below the standard value. The paper was folded to the rear and the front between the rotating rollers at a rate of 120 'double folds' per minute (Casey 1981).

\section{Folding endurance ANOVA analysis}

Table 6 shows the analysis of ANOVA for folding endurance. The Prob. F at SMSS for the linear and quadratic model was at 0.0066 and 0.3059 (insignificant).

Table 6. Folding Endurance ANOVA Analysis

\begin{tabular}{|c|c|c|c|c|}
\hline $\begin{array}{c}\text { Paper } \\
\text { Mechanical } \\
\text { Properties }\end{array}$ & Model & $\begin{array}{c}\text { Sequential Model } \\
\text { Sum of Squares } \\
\text { (SMSS)* }\end{array}$ & $\begin{array}{c}\text { Lack of Fit Test } \\
(\text { LOF) }\end{array}$ & $\begin{array}{c}\text { Model Summary } \\
\text { Statistic (MSS) }\end{array}$ \\
\hline $\begin{array}{c}\text { Folding } \\
\text { endurance, } \\
\log _{10}\end{array}$ & Linear & $\begin{array}{c}\text { F-value }=5.89 \\
\text { Prob. F }=0.0066\end{array}$ & $\begin{array}{c}\text { F-value }=0.57 \\
\text { Prob. F }=0.7938\end{array}$ & $\begin{array}{c}\mathrm{R}^{2}=0.3665 \\
\text { PRESS }=2.38\end{array}$ \\
\cline { 2 - 5 } & Quadratic & $\begin{array}{c}\text { F-value }=1.39 \\
\text { Prob. } F=0.3059\end{array}$ & $\begin{array}{c}\text { F-value }=0.23 \\
\text { Prob. F }=0.9320\end{array}$ & $\begin{array}{c}\mathrm{R}^{2}=0.3173 \\
\text { PRESS }=2.56\end{array}$ \\
\hline
\end{tabular}

${ }^{*}$ Choose model with significant Prob. F (Prob. F $<0.05$ )

\# Choose model with insignificant Prob. $F$ (Prob. $F>0.10$ )

$\ddagger$ Choose model with high $\mathrm{R}^{2}$ and low PRESS 
The value of insignificant quadratic model was better than the linear model with higher LOF at 0.9320 compared with 0.7938 . However, the linear model was selected due to its higher $\mathrm{R}^{2}$ and lower PRESS. The response surface in Eq. 3 represents the linear model for folding endurance.

$$
\text { Folding endurance, } \log _{10}=+5.43-0.010 \mathbf{T}-5.371 \times 10^{-3} \mathbf{t}-0.066 \mathbf{A}
$$

\section{Effect of pulping factors on folding endurance}

The folding endurance perturbation plot shows that these three pulping factors affect the durability of the folding endurance (Fig. 3). The alkaline and pulping time gave more impact to the folding endurance. However, the pulping temperature and alkaline were selected to represent the $\mathrm{X}$ - and $\mathrm{Y}$-axis, respectively, to facilitate the comparison between the mechanical properties of paper. When the percentage of alkaline and the pulping temperature increased, the folding endurance decreased. This is because alkali and high temperature causes cellulose degradation and weaken the fibers (Xu et al. 2020).

Folding endurance relates to tensile strength. When the tensile strength decreased, the endurance folding also decreased. It was also influenced by the bonding strength, prolongation, and flexibility. Generally, when the strength of the bursting and tensile strength increased, the folding endurance also rose. However, moisture content also plays a role in the strength of the properties. If the moisture content increases, bonding strength decreased, but the fiber flexibility improves. Although the flexibility has a small impact on the tensile and bursting strength, the increasing fiber flexibility decreases the tensile and bursting strength (Nissan 1977; Lund et al. 2012; Choi et al. 2016).

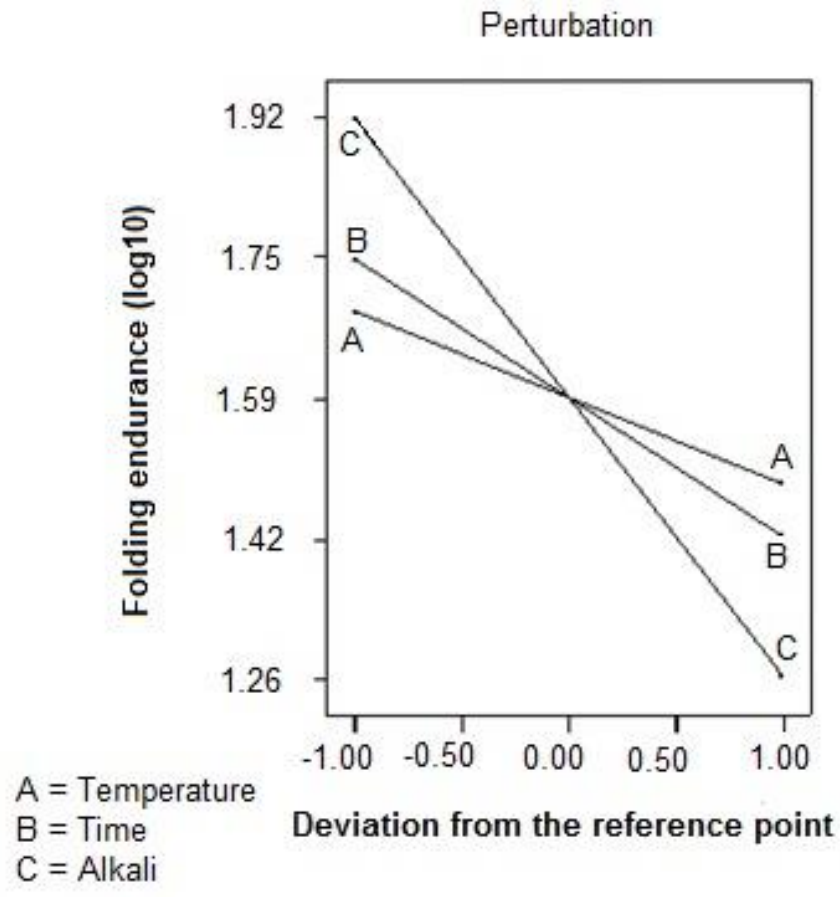

Fig. 3. Folding endurance perturbation plot 


\section{Bursting Strength}

Bursting strength is determined by the pressure required to break a specimen, and it relates to the tensile strength and the surface area of a paper. It is useful for testing of paper and board for packaging purposes (Browning 1977). Bursting strength is known as the 'Mullen' or 'pop' test. Burst strength is susceptible to the type, content, and amount of fibers present in the paper (ASTM D774 1963). Table 3 shows the bursting index response, which ranged from 4.17 to $5.80 \mathrm{kPa} . \mathrm{m}^{2} / \mathrm{g}$.

\section{Bursting Index ANOVA Analysis}

Table 7 shows that both the linear and quadratic model achieved Prob. F $>0.05$, but they were judged to be still acceptable because the value was not too far from the required value, i.e. $<0.05$. Observation at LOF showed that both models had insignificant value. MSS strengthened the selection of linear model because it has high $\mathrm{R}^{2}$ and low PRESS. Equation 4 represents the linear response surface plot for the bursting index.

Bursting index $\left(\mathrm{kPa} . \mathrm{m}^{2} / \mathrm{g}\right)=+8.63-0.014 \boldsymbol{T}-3.410 \times 10^{-3} \boldsymbol{t}-0.033 \boldsymbol{A}$

Table 7. Bursting Index ANOVA Analysis

\begin{tabular}{|c|c|c|c|c|}
\hline $\begin{array}{c}\text { Paper } \\
\text { mechanical } \\
\text { properties }\end{array}$ & Model & $\begin{array}{c}\text { Sequential Model } \\
\text { Sum of Squares } \\
(\text { SMSS) }\end{array}$ & $\begin{array}{c}\text { Lack of Fit Test } \\
(\text { LOF) }\end{array}$ & $\begin{array}{c}\text { Model Summary } \\
\text { Statistic (MSS) } \ddagger\end{array}$ \\
\hline $\begin{array}{c}\text { Bursting } \\
\text { index, } \\
\text { kPa.m } 2 / g\end{array}$ & Linear & $\begin{array}{c}\text { F-value }=1.89 \\
\text { Prob. } F=0.1713\end{array}$ & $\begin{array}{c}\text { F-value }=1.01 \\
\text { Prob. } F=0.5350\end{array}$ & $\begin{array}{c}\mathrm{R}^{2}=-0.0144 \\
\text { PRESS }=3.02\end{array}$ \\
\cline { 2 - 5 } & Quadratic & $\begin{array}{c}\text { F-value }=2.23 \\
\text { Prob. } F=0.1257\end{array}$ & $\begin{array}{c}\text { F-value }=0.38 \\
\text { Prob. } F=0.8469\end{array}$ & $\begin{array}{c}\mathrm{R}^{2}=-0.0586 \\
\text { PRESS }=3.15\end{array}$ \\
\hline
\end{tabular}

${ }^{*}$ Choose model with significant Prob. F (Prob. F $<0.05$ )

\# Choose model with insignificant Prob. F (Prob. F $>0.10$ )

¥ Choose model with high $\mathrm{R}^{2}$ and low PRESS

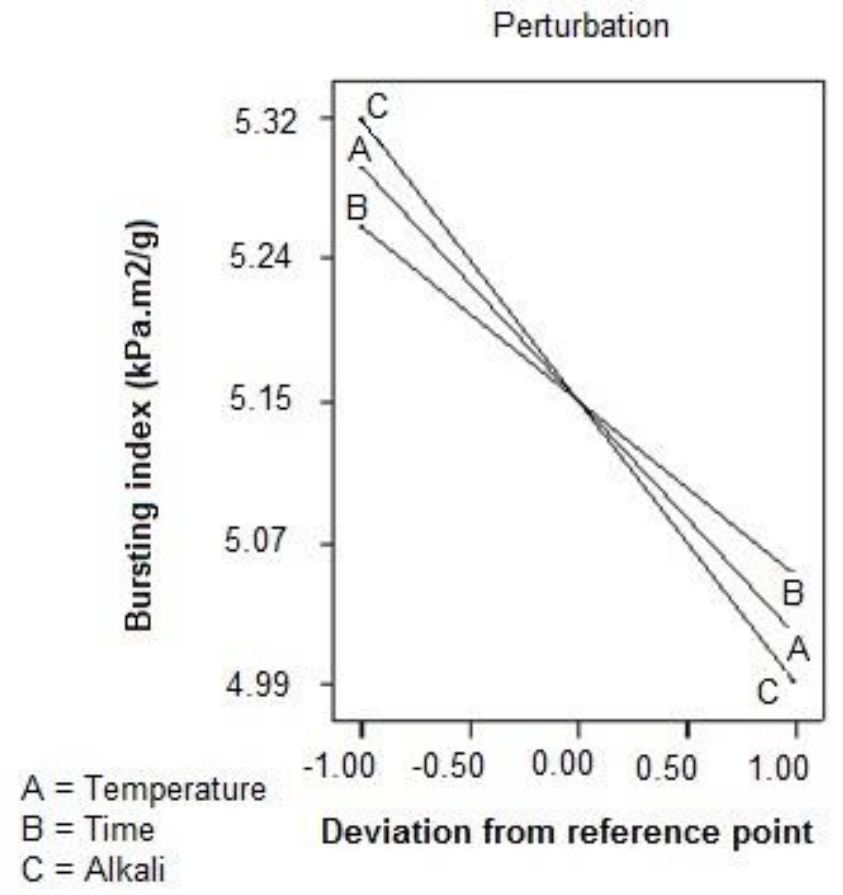

Fig. 4. Bursting index perturbation plot 


\section{Effect of pulping factors on bursting index}

The bursting index perturbation plot (Fig. 4) shows that the temperature and alkali were represented as the $\mathrm{X}$ - and $\mathrm{Y}$-axis, respectively. Increasing the pulping time decreased the bursting index as the time changed from $60 \mathrm{~min}$ to $90 \mathrm{~min}$ and $120 \mathrm{~min}$. Decreased alkali and temperature lead to an increased bursting index. The bursting index is associated with average fiber length and level of bonding between fibers (Zhao et al. 2002).

Bursting index is closely related to hydrogen bonding between the fibers. With stronger hydrogen bonding between fibers, the bursting index rises because higher forces are needed to break the surface of the paper sample. This will happen on the paper that has high strength fibers.

Based on this study, the bursting index decreased with the increasing of the pulping factors because fiber has become weak as the result of degradation at higher pulping temperature, longer time, and higher alkaline charge. Therefore, the hydrogen bonding between fibers becomes weak, and the surface of the paper becomes fragile when the pressure was applied and thus decreased the bursting index (Wutisatwongkul et al. 2016; Ikramullah et al. 2018).

\section{Zero - Span Tensile Strength}

Tensile strength also can be determined by using zero-span tensile, which is measured using special tools, where two jaws are clamped side by side without any span between the jaws. The principle of the zero-span test measures the strength of individual randomly oriented fibers in the paper. The ratio between normal tensile to zero-span can be used to estimate the degree of bonding between the fibers. It is useful for measuring the individual fiber strength loss caused by extreme bleaching, high acidity, and the effects of other degradation (Casey 1981).

\section{Zero-span ANOVA analysis}

Based on Table 8, SMSS showed that the linear model was chosen for having a value of 0.0769 compared to 0.4938 for the quadratic model. The value of linear model in LOF also was greater than the values for the quadratic model. Referring to MSS, it is apparent that the linear model is most appropriate because of its higher $\mathrm{R}^{2}$ and lower PRESS. Equation 5 describes the plot surface response for the zero-span linear model.

$$
\text { Zero-span, } \mathrm{N}=+72.67-0.031 \boldsymbol{T}-0.092 \boldsymbol{t}-0.59 \boldsymbol{A}
$$

Table 8. Zero-span Tensile Strength ANOVA Analysis

\begin{tabular}{|c|c|c|c|c|}
\hline $\begin{array}{c}\text { Paper } \\
\text { mechanical } \\
\text { properties }\end{array}$ & Model & $\begin{array}{c}\text { Sequential Model } \\
\text { Sum of Squares } \\
(\text { SMSS) }\end{array}$ & $\begin{array}{c}\text { Lack of Fit Test } \\
(\text { LOF })^{\#}\end{array}$ & $\begin{array}{c}\text { Model Summary } \\
\text { Statistic (MSS) }\end{array}$ \\
\hline \multirow{3}{*}{ Zero-span, N } & Linear & $\begin{array}{c}\text { F-value }=2.75 \\
\text { Prob. } F=0.0769\end{array}$ & $\begin{array}{c}\text { F-value }=1.49 \\
\text { Prob. } F=0.3472\end{array}$ & $\begin{array}{c}\mathrm{R}^{2}=-0.0994 \\
\text { PRESS }=720.80\end{array}$ \\
\cline { 2 - 5 } & Quadratic & $\begin{array}{c}\text { F-value }=0.97 \\
\text { Prob. } F=0.4938\end{array}$ & $\begin{array}{c}\text { F-value }=1.70 \\
\text { Prob. } F=0.2864\end{array}$ & $\begin{array}{c}\mathrm{R}^{2}=-1.2680 \\
\text { PRESS }=1486.98\end{array}$ \\
\hline
\end{tabular}

${ }^{*}$ Choose model with significant Prob. F (Prob. F $<0.05$ )

\# Choose model with insignificant Prob. F (Prob. F $>0.10$ )

$\ddagger$ Choose model with high $\mathrm{R}^{2}$ and low PRESS 


\section{Effect of pulping factors on zero-span}

Figure 5 shows the zero-span perturbation plot. Time and alkaline had much more influence on zero-span than temperature. However, the temperature also affected the zerospan because it decreased when the temperature is increased from $160{ }^{\circ} \mathrm{C}$ to $170{ }^{\circ} \mathrm{C}$ and $180{ }^{\circ} \mathrm{C}$. This means that zero-span tensile strength decreased with the increasing of temperature, as high temperatures cause more cellulose and hemicellulose degradation and thus weaken the fibers.

When alkalinity increased, zero-span decreased. This was due to severe degradation on the fiber cellulose chains, which weakened the individual fibers. The use of longer pulping time removed more lignin but at the same time shortened the molecular chains and thus weaken the cellulose fiber.

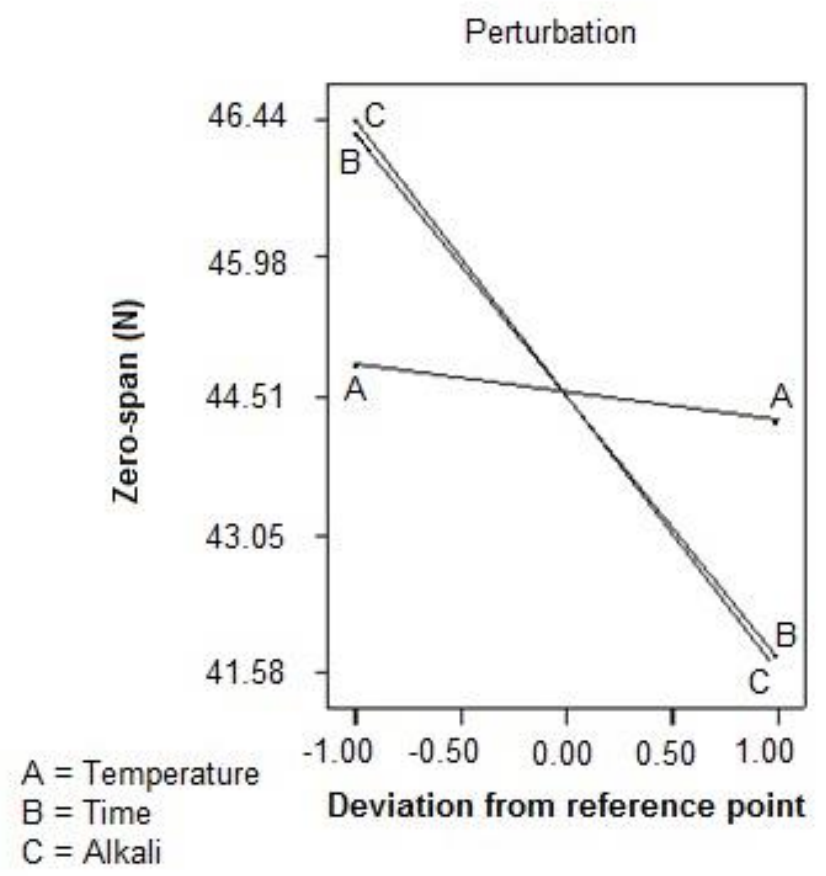

Fig. 5. Zero-span perturbation plot

\section{Paper Optical Properties}

\section{Brightness}

The actual brightness refers to the enlightenment or reflectance from the entire paper. It depends on the overall spectral reflectance from a paper, the condition of visibility (lighting), and characteristics of the viewer. The brightness of the manufacturing paper is based on the measurement of light reflection from the white or almost white paper on a blue spectrum wave, with light wave dominant at $457 \mathrm{~nm}$ (Casey 1981). Table 3 shows the brightness range of soda-AQ pulping paper between 39.6 and $56.4 \%$. This is considered a high brightness value for the unbleached paper.

\section{Brightness ANOVA analysis}

Table 9 shows the analysis of ANOVA for the brightness response. At SMSS, it is clear that the linear model is most appropriate because it has a significant value of $<0.0001$. The LOF for both models did not meet the requirement of $>0.10$. The observation on MSS 
strengthened the selection of linear model with higher $\mathrm{R}^{2}$ values and lower PRESS. Equation 6 represents the linear model of brightness.

$$
\text { Brightness }(\%)=+11.34+0.12 \boldsymbol{T}+0.016 t+0.73 \boldsymbol{A}
$$

\section{Effect of pulping factors on brightness}

The brightness perturbation plot (Fig. 6) shows that the temperature and alkaline highly affected the brightness. Brightness and pulping time showed a proportional increment. Longer pulping time allows more lignin to be dissolved and thus increases the brightness of the paper.

Table 9. Brightness ANOVA Analysis

\begin{tabular}{|c|c|c|c|c|}
\hline $\begin{array}{c}\text { Paper Optical } \\
\text { Properties }\end{array}$ & Model & $\begin{array}{c}\text { Sequential Model } \\
\text { Sum of Squares } \\
\text { (SMSS)* }\end{array}$ & $\begin{array}{c}\text { Lack of Fit Test } \\
(\text { LOF) }\end{array}$ & $\begin{array}{c}\text { Model Summary } \\
\text { Statistic (MSS) }\end{array}$ \\
\hline \multirow{3}{*}{ Brightness, \% } & Linear & $\begin{array}{c}\text { F-value }=14.28 \\
\text { Prob. } \mathrm{F}<0.0001\end{array}$ & $\begin{array}{c}\text { F-value }=31.30 \\
\text { Prob. } \mathrm{F}=0.0007\end{array}$ & $\begin{array}{c}\mathrm{R}^{2}=0.5331 \\
\text { PRESS }=132.26\end{array}$ \\
\cline { 2 - 5 } & Quadratic & $\begin{array}{c}\mathrm{F} \text {-value }=1.50 \\
\text { Prob. } \mathrm{F}=0.2705\end{array}$ & $\begin{array}{c}\mathrm{F} \text {-value }=35.71 \\
\text { Prob. } \mathrm{F}=0.0006\end{array}$ & $\begin{array}{c}\mathrm{R}^{2}=-0.0584 \\
\text { PRESS }=299.82\end{array}$ \\
\hline
\end{tabular}

${ }^{*}$ Choose model with significant Prob. F (Prob. F $<0.05$ )

\# Choose model with insignificant Prob. F (Prob. F $>0.10$ )

$\ddagger$ Choose model with high $\mathrm{R}^{2}$ and low PRESS

\section{Perturbation}

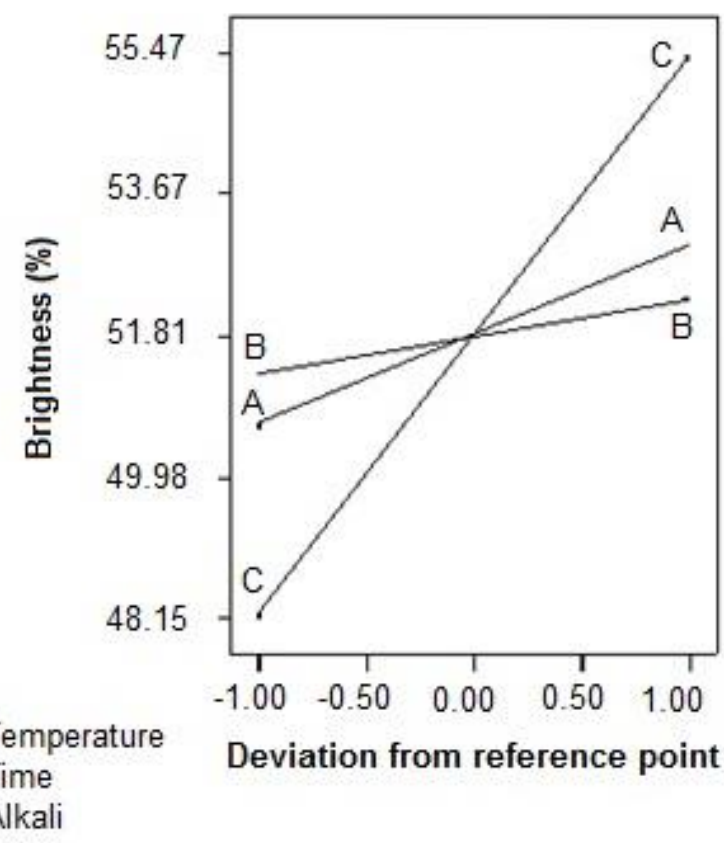

Fig. 6. Brightness perturbation plot

The brightness increased with an increase in alkali and temperature. This is because when alkaline increased, more lignin was dissolved or removed. Lignin has chromophore groups that work to absorb light, which contributes to paper darkening. Therefore, with lignin removal, chromophore groups were eliminated, and the process of absorption of light by chromophore was blocked because it is responsible for making the paper dark. The 
higher pulp severity will lead to a brighter paper (Ikramullah et al. 2018; Hedjazi et al. 2009).

As the temperature rises, the rate of delignification also rises (Mims et al. 1989). More lignin can be eliminated at high temperatures and cause the brightness of paper increased due to the depletion of the light-absorbing material (lignin).

\section{Opacity}

Table 10 shows the analysis of ANOVA for the opacity response. The opacity measurement is used to determine the ability of the paper to hide the contrast. A printed paper needs to have enough opacity to remove the printing shadow on the next page or to be printed on both sides of the paper. Bond paper, books, paper, and newspapers are examples of papers that required high opacity (ASTM D589 1963). Table 3 shows that the range of opacity was between 94.92 and $98.26 \%$. The difference of $3.34 \%$ was too small to indicate that pulping factors affect the opacity properties.

Table 10. Opacity ANOVA Analysis

\begin{tabular}{|l|l|l|l|l|}
\hline $\begin{array}{l}\text { Paper Optical } \\
\text { Properties }\end{array}$ & Model & $\begin{array}{l}\text { Sequential Model } \\
\text { Sum of Squares } \\
(\text { SMSS) }\end{array}$ & $\begin{array}{l}\text { Lack of Fit Test } \\
(\text { LOF) }\end{array}$ & $\begin{array}{l}\text { Model Summary } \\
\text { Statistic (MSS) }\end{array}$ \\
\hline \multirow{3}{*}{ Opacity, \% } & Linear & $\begin{array}{l}\text { F-value }=2.58 \\
\text { Prob. F }=0.0895\end{array}$ & $\begin{array}{l}\text { F-value }=6.42 \\
\text { Prob. F }=0.0262\end{array}$ & $\begin{array}{l}\mathrm{R}^{2}=-0.1970 \\
\text { PRESS }=15.56\end{array}$ \\
\cline { 2 - 5 } & Quadratic & $\begin{array}{l}\text { F-value }=1.14 \\
\text { Prob. F }=0.4082\end{array}$ & $\begin{array}{l}\text { F-value }=7.99 \\
\text { Prob. F }=0.0198\end{array}$ & $\begin{array}{l}\mathrm{R}^{2}=-1.8051 \\
\text { PRESS }=36.67\end{array}$ \\
\hline
\end{tabular}

${ }^{*}$ Choose model with significant Prob. F (Prob. F $<0.05$ )

\# Choose model with insignificant Prob. F (Prob. F >0.10)

$\ddagger$ Choose model with high $\mathrm{R}^{2}$ and low PRESS

Although the ranges of the differences were small, statistically, SMSS showed a significant value for the linear opacity model (Table 10). Both models did not meet the LOF values at F-value of $>0.10$. However, the MSS observations favored the linear models based on the value of higher $\mathrm{R}^{2}$ and lower PRESS. The response surface plot for opacity is represented by Eq. 7 .

$$
\text { Opacity }(\%)=+88.50+0.047 \boldsymbol{T}+9.205 \times 10^{-3} \boldsymbol{t}-0.026 \boldsymbol{A}
$$

\section{Effect of pulping factors on opacity}

The most influential factors effect on the opacity were time and temperature, as described by the opacity perturbation plot (Fig. 7).

Alkali had less effect on the opacity and was set constant at $20 \%, 25 \%$, and $30 \%$. Opacity increased as time increased. Longer pulping time allows more lignin to be dissolved, and according to Casey (1980), longer pulping time decreases the fiber dimensions, resulting in increased light scattering.

The increase in temperature also increases the paper opacity. This phenomenon occurs due to the fiber lumen collapse at high temperatures (Scallen and Borch 1976). The collapsed fiber results in decreased lumen scattering power and increased absorption power. Casey (1980) stated that at low scattering power and high absorption power, paper reflectivity would be decreased and this makes the paper opacity increased. In contrast with the alkali factors, when the alkali percentage increased, the value of the opacity decreased. This is because high alkaline pulp results in brighter paper and thus reduces the paper opacity. 


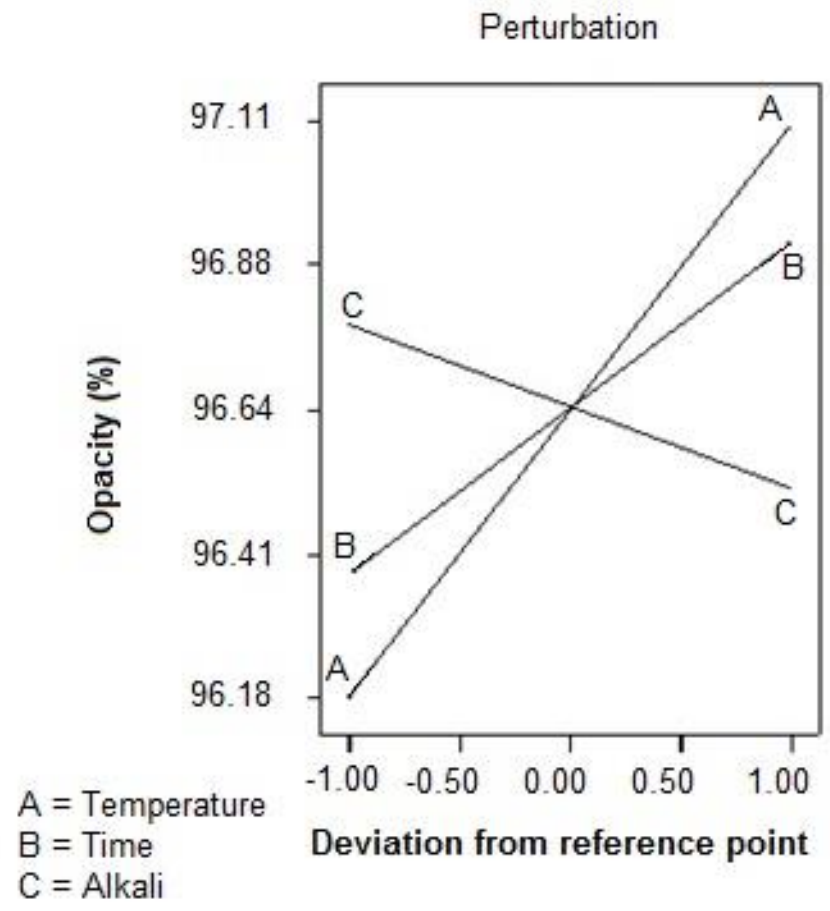

Fig. 7. Opacity perturbation plot

\section{Optimization}

Optimization is the process of finding the optimum value for each pulping factor to obtain the optimal values of an experimental outcome. In the experimental design, the goal of each response was identified. Objectives that can be achieved are the maximum value, minimum value, the value to be reached (target), and the value in the range.

To achieve high tensile, tearing, folding endurance, bursting, zero span index, brightness, and opacity, the pulping conditions were conducted at $160{ }^{\circ} \mathrm{C}, 60 \mathrm{~min}$ pulping time, and $27.30 \%$ alkali. Table 11 shows the predicted and actual values for all mechanical and optical paper properties. The mathematical model derived from the experimental design gave good prediction based on the low standard deviation from the predicted and actual values. The low pulping condition was sufficient to achieve high paper properties due to low lignin content in non-wood material such as EFB compared to wood material. This result is significant to avoid the unnecessary degradation on the EFB fiber thus leading to decrease the EFB paper strength.

Table 11. Comparison on Predicted and Actual Values from the Pulping Optimization

\begin{tabular}{|c|c|c|c|}
\hline Paper Properties & Predicted Value & Actual Value & $\begin{array}{c}\text { Standard } \\
\text { Deviation }\end{array}$ \\
\hline Tensile index $(\mathrm{Nm} / \mathrm{g})$ & 26.77 & 22.87 & 3.7421 \\
\hline Tearing index $\left(\mathrm{mN} \cdot \mathrm{m}^{2} / \mathrm{g}\right)$ & 7.95 & 6.62 & 0.8349 \\
\hline Folding endurance $\left(\mathrm{log}_{10}\right)$ & 1.70 & 1.43 & 0.3338 \\
\hline Bursting index $\left(\mathrm{kPa} \cdot \mathrm{m}^{2} / \mathrm{g}\right)$ & 5.32 & 5.45 & 0.3705 \\
\hline Zero-span $(\mathrm{N})$ & 46.23 & 45.57 & 5.1998 \\
\hline Brightness $(\%)$ & 51.80 & 49.60 & 2.1942 \\
\hline Opacity $(\%)$ & 95.84 & 91.72 & 0.7419 \\
\hline
\end{tabular}




\section{CONCLUSIONS}

1. The effect of pulping condition with alkali charge $(A)$, pulping temperature $(T)$, and pulping time $(t)$ ranged between 20 and $30 \%$ of $\mathrm{NaOH}, 160$ and $180^{\circ} \mathrm{C}$, and 60 and 120 min were conducted on the oil palm EFB fiber.

2. The mathematical relationship generated showed that the optimum pulping condition were at $27.30 \%$ alkali charge, $160{ }^{\circ} \mathrm{C}$, and $60 \mathrm{~min}$. This combination of low pulping conditions level produced $26.8 \mathrm{~N} . \mathrm{m} / \mathrm{g}$ tensile index, $7.95 \mathrm{mN} . \mathrm{m}^{2} / \mathrm{g}$ tearing index, 5.32 $\mathrm{kPa} . \mathrm{m}^{2} / \mathrm{g}$ bursting index, $1.70 \log _{10}$ folding endurance, $46.2 \mathrm{~N}$ zero-span tensile strength, $51.8 \%$ brightness, and $95.8 \%$ opacity.

3. This economical pulping properties has high potential to be implemented in pulp and paper industry with more environmentally pulping process.

\section{ACKNOWLEDGMENTS}

The authors express their appreciation to SABUTEK Sdn. Bhd., Teluk Intan, Perak, for providing the raw material for this study. The authors also acknowledge FRGS/1/2018/TK10/UITM/02/4 as fund provider.

\section{REFERENCES CITED}

Agustin, M. B., Penttilä, P. A., Lahtinen, M., and Mikkonen, K. S. (2019). "Rapid and direct preparation of lignin nanoparticles from alkaline pulping liquor by mild ultrasonication," ACS Sustainable Chemistry \& Engineering 7(24), 19925-19934. DOI: 10.1021/acssuschemeng.9b05445

American Society for Testing and Material (ASTM) (1963). Paper and Paperboard; Characteristics, Nomenclature and Significance of Test, $3^{\text {rd }}$ Ed., Philadelphia, USA.

Azizi Mossello, A., Harun, J., Resalati, H., Ibrahim, R., Fallah Shams, S., and Md Tahir, P. (2010). "New approach to use of kenaf for paper and paperboard production," BioResources 5(4), 2112-2122.

Browning, B. L. (1977). Analysis of Paper, $2^{\text {nd }}$ Ed., Marcel Dekker, New York, NY. Casey, J. P. (1980). Pulp and Paper: Chemistry and Chemical Technology, Vol. I, $3^{\text {rd }}$ Ed., John Wiley and Sons, New York, NY.

Casey, J. P. (1981). Pulp and Paper: Chemistry and Chemical Technology, Vol. III, $3^{\text {rd }}$ Ed., John Wiley and Sons, New York, NY.

Casey, J. P. (1983). Pulp and Paper: Chemistry and Chemical Technology, John Wiley and Sons, New York, NY.

Choi, K. H., Kim, A. R., and Cho, B. U. (2016). "Effects of alkali swelling and beating treatments on properties of kraft pulp fibers," BioResources 11(2), 3769-3782. DOI: 10.15376/biores.11.2.3769-3782

Elzaki, O. T., Khider, T. O., Omer, S. H., Mohieldin, S. D., and Shomeina, S. K. (2020). "Suitability of Sudanese pearl millet stalks Pennisetum glaucum (L.) for alkaline pulping with additives," Songklanakarin Journal of Science \& Technology 42(1). DOI: $10.14456 /$ sjst-psu.2020.16 
Fernández-Rodríguez, J., Erdocia, X., Hernández-Ramos, F., Alriols, M. G., and Labidi, J. (2019). "Lignin separation and fractionation by ultrafiltration," in: Separation of Functional Molecules in Food by Membrane Technology, Academic Press, pp. 229265. DOI: 10.1016/B978-0-12-815056-6.00007-3

Gomes, R. M., and da Silva Júnior, F. G. (2020). "Impact of sulfidity on the kraft pulping of eucalyptus," BioResources 15(2),3945-3961.DOI:10.15376/biores.15.2.3945-3961

Hart, P. W., and Rudie, A. W. (2014). "Anthraquinone - A review of the rise and fall of a pulping catalyst," TAPPI Journal 13(10), 23-31.

Hedjazi, S., Kordsachia, O., Patt, R., Latibari, A. J., and Tschirner, U. (2009). "Alkaline sulfite-anthraquinone (AS/AQ) pulping of wheat straw and totally chlorine free (TCF) bleaching of pulps," Industrial Crops and Products 29(1), 27-36. DOI: 10.1016/j.indcrop.2008.03.013

Hyväkkö, U., Maltari, R., Kakko, T., Kontro, J., Mikkilä, J., Kilpeläinen, P., and Sipilä, J. (2019). "On the effect of hot-water pretreatment in sulfur-free pulping of aspen and wheat straw," ACS Omega. DOI.org/10.1021/acsomega.9b02619

Ikramullah, I., Rizal, S., Thalib, S., and Huzni, S. (2018). "Hemicellulose and lignin removal of typha fiber by alkali treatment," IOP Conference Series. Material Science and Engineering, 352, 012019 DOI: 10.1088/1757-889x/352/1/01/2019

Jiménez, L., Serrano, L., Rodríguez, A., and Sánchez, R. (2009). "Soda-anthraquinone pulping of palm oil empty fruit bunches and beating of the resulting pulp," Bioresource Technology 100(3), 1262-1267. DOI: 10.1016/j.biortech.2008.08.013

Li, Z., Zeng, H., Xiao, X., Cao, J., Yang, C., and Zhang, K. (2019). "Resource value flow analysis of paper-making enterprises: A Chinese case study," Journal of Cleaner Production 213, 577-587. DOI: 10.1016/j.jclepro.2018.12.158

Loh, S. K. (2017). "The potential of the Malaysian oil palm biomass as a renewable energy source," Energy Conversion and Management 141, 285-298. DOI: 10.1016/j.enconman.2016.08.081

Lund, K., Sjöström, K., and Brelid, H. (2012). “Alkali extraction of kraft pulp fibers: Influence on fiber and fluff pulp properties," Journal of Engineered Fibers and Fabrics 7(2). DOI: 10.1177/155892501200700206

Mahmud, K. N., and Zakaria, Z. A. (2020). "Pyrolytic products from oil palm biomass and its potential applications," in: Valorisation of Agro-industrial Residues-Volume II: Non-Biological Approaches, Springer, Cham., pp. 225-236. DOI: 10.1007/978-3030-39208-6_11

Maloney, T. C., Li, T. Q., Weise, U. L. R. I. C. H., and Paulapuro, H. A. N. N. U. (1997). "Intra-and inter-fibre pore closure in wet pressing," Appita Journal 50(4), 301-306.

Mannai, F., Elhleli, H., Khiari, R., and Moussaoui, Y. (2019). "Cellulosic fibers from lignocellulosic biomass for papermaking applications," in: Food Waste as a Resource. IntechOpen. DOI: 10.5772/intechopen.88388

Masrol, S. R., Ibrahim, M. H. I., Adnan, S., Talib, M. R., and Sian, L. L. (2017). "Effects of soda-anthraquinone pulping variables on the durian rind pulp and paper characteristics: A preliminary test," in: IOP Conference Series: Materials Science and Engineering, International Research and Innovation Summit (IRIS2017), Melaka, Malaysia. DOI: 10.1088/1757-899X/226/1/012175

Moll, H. A. J. (1987). The Economics of Oil Palm. Economics of Crops in Developing Countries No. 2, Pudoc Wageningen, Netherlands.

Malaysian Palm Oil Promotion Council (MPOPC) (2004). (http://www.mpopc.org.my), Kuala Lumpur, Malaysia. 
Mutsaers, H. J. W. (2019). "The challenge of the oil palm: Using degraded land for its cultivation," Outlook on Agriculture 48(3), 190-197. DOI: 10.1177/0030727019858720

Nissan, A. H. (1977). Lectures on Fiber Science in Paper: Presented in September 1974 at the Institute of Physical Chemistry of the University of Uppsala, Joint textbook Committee of the Paper Industry.

Nurul Husna, M. H., Suhaimi, M., and Rushdan, I. (2014). "Properties of Gigantochloa scortechinii paper enhancement by beating revolution," Journal of Tropical Resources and Sustainable Science 2, 59-67.

Nurul Husna, M. H., Mazlan, I., and Nor Yuziah, M. Y. (2018). "Response surface methodology on the effects of soda-anthraquinone pulping conditions on oil palm empty fruit bunches pulp properties," Malaysian Journal of Analytical Sciences 22(2), 203-218. DOI: 10.17576/mjas-2018-2202-05

Omer, S. H., Khider, T. O., Elzaki, O. T., Mohieldin, S. D., and Shomeina, S. K. (2019). Application of soda-AQ pulping to agricultural waste (okra stalks) from Sudan," BMC Chem Eng 1, 6 (2019). DOI: 10.1186/s42480-019-0005-9

Onoja, E., Chandren, S., Abdul Razak, F. I., Mahat, N. A., and Wahab, R. A. (2018). "Oil palm (Elaeis guineensis) biomass in Malaysia: The present and future prospects," Waste and Biomass Valorization 10, 2099-2117. DOI: 10.1007/s12649-018-0258-1

Pereira, P. H. F., Souza, N. F., Ornaghi Jr, H. L., and de Freitas, M. R. (2020). "Comparative analysis of different chlorine-free extraction on oil palm mesocarp fiber," Industrial Crops and Products 150, article no. 112305. DOI: 10.1016/j.indcrop.2020.112305

Poh, P. E., Wu, T. Y., Lam, W. H., Poon, W. C., and Lim, C. S. (2020). "Oil palm plantation wastes," in: Waste Management in the Palm Oil Industry, pp. 5-20. Springer, Cham. DOI: 10.1007/978-3-030-39550-6_2

Pye, O. (2019). "Commodifying sustainability: Development, nature and politics in the palm oil industry," World Development 121, 218-228. DOI:

10.1016/j.worlddev.2018.02.014

Przybysz, P., Dubowik, M., Kucner, M. A., Przybysz, K., and Buzała, K. P. (2016). "Contribution of hydrogen bonds to paper strength properties," PloS one 11(5). DOI: 10.1371/journal.pone.0155809

Rahman, A. Z. A., and Amin, N. A. S. (2019). "Environmental sustainability assessment of palm lignocellulosic biomass pretreatment methods," Chemical Engineering Transactions 72, 13-18. DOI: 10.3303/CET1972003

Samp, J. C. (2008). "A comprehensive mechanism for anthraquinone mass transfer in alkaline pulping," Ph.D. thesis, Georgia Institute of Technology, 120 pages, Atlanta.

Scallen, A. M., and Borch, J. (1976). "Fundamental parameters affecting the opacity and brightness of uncoated paper," in: Fundamental Properties of Paper Related to Its Uses, Vol. I, Mechanical Engineering Publication Limited, London.

Schmied, F. J., Teichert, C., Kappel, L., Hirn, U., Bauer, W., and Schennach, R. (2013). "What holds paper together: Nanometre scale exploration of bonding between paper fibres," Scientific Reports 3(1), 1-6. DOI: 10.1038/srep02432

Shakhes, J., Zeinaly, F., Marandi, M. A., and Saghafi, T. (2011). "The effects of processing variables on the soda and soda-AQ pulping of kenaf bast fiber," BioResources 6(4), 4626-4639. 
Soloi, S., and Hou, E. K. Z. (2019). "The Potential of oil palm leaf fibre in paper-making industry," in: Journal of Physics: Conference Series, Vol. 1358(1), p. 012005. IOP Publishing. DOI:10.1088/1742-6596/1358/1/012005

Tan, Y. D., and Lim, J. S. (2019). "Feasibility of palm oil mill effluent elimination towards sustainable Malaysian palm oil industry," Renewable and Sustainable Energy Reviews 111, 507-522. DOI: 10.1016/j.rser.2019.05.043

TAPPI T205 cm-88 (1994a). "Forming handsheets for physical tests of pulp," TAPPI Press, Atlanta, GA.

TAPPI T220 om-88 (1994b). "Physical testing of pulp handsheets," TAPPI Press, Atlanta, GA.

TAPPI T404 cm-92 (1994c). "Tensile breaking strength and elongation of paper and paperboard (using pendulum type tester)," TAPPI Press, Atlanta, GA.

TAPPI T414 om-88 (1994d). "Internal tearing resistance of paper (Elmendorf type method)," TAPPI Press, Atlanta, GA.

TAPPI T423 om-88 (1994e). "Folding endurance of paper (Schopper type tester)," TAPPI Press, Atlanta, GA.

TAPPI T403 om-91 (1994f). "Bursting strength of paper," TAPPI Press, Atlanta, GA.

TAPPI T231 cm-85 (1994g). "Zero-span breaking strength of pulp (dry zero-span tensile)," TAPPI Press, Atlanta, GA.

TAPPI T452 om-92 (1994h). "Brightness of pulp, paper, and paperboard (directional reflectance at $457 \mathrm{~nm})$," TAPPI Press, Atlanta, GA.

TAPPI T425 om-92 (1994i). "Opacity of paper (15/d geometry, illuminant A/2, 89\% reflectance backing and paper backing)," TAPPI Press, Atlanta, GA.

Tutus, A., Cicekler, M., and Kucukbey, N. (2016). "Pulp and paper production from bitter orange (Citrus aurantium L.) woods with soda-AQ method," Kastamonu Univ., Journal of Forestry Faculty 16(1), 14-18.

Wutisatwongkul, J., Thavarungkul, N., Tiansuwan, J., and Termsuksawad, P. (2016). "Influence of soda pulping variables on properties of pineapple (Ananas comosus merr.) leaf pulp and paper studied by face-centered composite experimental design," Advances in Materials Science and Engineering, 2016. DOI: 10.1155/2016/8915362

$\mathrm{Xu}$, E., Wang, D., and Lin, L. (2020). "Chemical structure and mechanical properties of wood cell walls treated with acid and alkali solution," Forests 11(1), 87. DOI: 10.3390/f11010087

Zhao, J., Li, X., Qu, Y., and Gao, P. (2002). "Xylanese pretreatment leads to enhanced soda pulping of wheat straw," Enzyme and Microbial Technology 30(6), 734-740. DOI: 10.1016/S0141-0229(02)00050-9

Article submitted: Feb. 12, 2020; Peer review completed: April 11, 2020; Revised version received: April 26, 2020; Tentatively accepted: May 6, 2020; Accepted: May 10, 2020; Published: May 14, 2020.

DOI: 10.15376/biores.15.3.5012-5031 